\title{
Correction: Spermatogonial stem cell sensitivity to capsaicin: An in vitro study
}

Sefika C Mizrak ${ }^{1,2^{*}}$, Bart M Gadella², Hatice Erdost ${ }^{3}$, Aytekin Ozer $^{3}$, Ans MM van Pelt ${ }^{1}$, Federica MF van Dissel-Emiliani ${ }^{4,2}$

Since publication of our article [1], we have realised that the legend of Figure one needs to be corrected and should read as follows:

"Photomicrograph of Gc-5spg and Gc-6spg stained with an anti-activated caspase 3 antibody and counterstained with Haemaluin as described in Materials and Methods. A, Gc-5spg culture treated with 200 uM CAP for $24 \mathrm{~h} \mathrm{~B}$, Gc-6spg culture treated with $250 \mathrm{uM}$ CAP during 48 h."

We apologise for any confusion this may have caused.

\section{Author details}

'Fertility Laboratory, Centre for Reproductive Medicine, Academic Medical Centre, Amsterdam, The Netherlands. ${ }^{2}$ Department of Biochemistry and Cell Biology, Faculty of Veterinary Medicine, Utrecht University, Utrecht, The Netherlands. ${ }^{3}$ Histology and Embryology Department, Faculty of Veterinary Medicine, Uludag University, Bursa, Turkey. ${ }^{4}$ Department of Equine Sciences, Faculty of Veterinary Medicine, Utrecht University, Utrecht, The Netherlands.

Received: 25 January 2011 Accepted: 28 January 2011

Published: 28 January 2011

\section{Reference}

1. Mizrak SC, Gadella BM, Erdost H, Ozer A, van Pelt AM, van Dissel-

Emiliani FM: Spermatogonial stem cell sensitivity to capsaicin: an in vitro study. Reprod Biol Endocrinol 2008, 6:52.

\footnotetext{
* Correspondence: S.C.Mizrak@amc.uva.nl

${ }^{1}$ Fertility Laboratory, Centre for Reproductive Medicine, Academic Medical Centre, Amsterdam, The Netherlands

Full list of author information is available at the end of the article
}

Submit your next manuscript to BioMed Central and take full advantage of:

- Convenient online submission

- Thorough peer review

- No space constraints or color figure charges

- Immediate publication on acceptance

- Inclusion in PubMed, CAS, Scopus and Google Scholar

- Research which is freely available for redistribution

Submit your manuscript at www.biomedcentral.com/submit 